\title{
Journal of Environmental \& Analytical Toxicology, Volume 7; Issue 1
}

\section{Tarek Heikal*}

Environmental Toxicology Research Unit, National Research Centre, Cairo, Egypt

Environment is classically defined by the surroundings where living beings use to have their resources for living. However, environment itself is suffering most for the limitless exploratory interferences of mankind. Environmental toxicology which is often referred to as 'entox' encompasses the multidisciplinary study of the possible repercussions of harmful physical, chemical and biological toxins on living organisms. Duffus has explained that environment toxicology research chiefly corresponds to the development of methods that can contribute in making correct assessment of biochemical responses and metabolic changes elicited due to exposure to toxic pollutants [1]. Ecotoxicology, a branch of entox, specifically deals with the ecological implications of pollution and bioaccumulation of natural and synthetic toxins. Majority of the research activities in the field of environmental toxicology emphasizes on the innovation and application of bioanalytical techniques for monitoring and regressing the levels and effects of environmental toxins.

The Journal of Environmental \& Analytical Toxicology (JEAT) targets the publication of research developments that address the issue of growing impacts of environmental pollution. The journal also serves as a platform for showcasing novel bio-analytical techniques that may be applicable in diminishing the adverse impacts of toxic pollutants. The current issue of the journal specifically highlighted the growing concern of water pollution. A number of articles published in the journal involved estimating the water quality index of natural and manmade water bodies. These articles aim to highlight the degrading quality of water and the biomedical and Eco toxicological discrepancies it may cause.

The most important and regrettably the most common medium of exposure to extremely toxic heavy metals and pollutants are through polluted water. Almost all cities rely on nearby rivers or lakes for water supply. The WHO has set some standard parameter values that the water sample needs to pass before being channelized to peoples' houses. While most authorities adhere to these standard practices, it has been observed that in many cases they are ignored. The article published by Saad et al. [2], reports one such water body, namely Mariout Lake, Alexandria. The authors did an extensive analysis on the various standard parameters as recommended by the WHO viz. TDS, BOD, COD, conductivity, mineral analysis etc. The authors observed that most of the values recorded were not under the recommended range of WHO, which makes the water unfit for domestic usage. Furthermore, the authors took samples from multiple places and pin pointed the places that are the origin of pollutant discharge.

In a similar study, Manohar et al. [3], conducted a water quality analysis of the Yatta Canal, Machakos County, Kenya. Just like the above explained study, the authors of the present study also conducted a water quality analysis to find out its applicability for irrigation purposes. The $\mathrm{pH}$, temperature, alkalinity, acidity, electrical conductivity, TDS and DO of the water samples were analyzed round the year and a comparative analysis was performed later to detect the seasonal variation in the values. It was a found that there occurred a significant seasonal variation, but thankfully, the annual average values were under the recommended values of FAO and Kenya's National Environment Management Authority. However, the turbidity (100.2 NTU) and nitrate concentration $(13.1 \mathrm{mg} / \mathrm{l})$ were deviating from the standard values in the rainy season. After making an overall assessment of the water quality the researchers recommended that the water can be used for irrigation in the dry seasons. The importance of the study lies in the fact that, if the irrigation water is polluted, the crop plants take in the toxic pollutants and xenobiotic compounds and deposit it in its tissues. These compounds then make their way into the human body. Therefore, monitoring irrigation water resources could help in preventing human exposure and bio-accumulation of toxic compounds right at the outset.

Another article published by Kumar et al. [4], also addressed the issue of water contamination and its un/suitability for drinking, domestic, industrial and agricultural processes. The authors conducted a thorough analysis of several physic-chemical parameters of surface and ground water of Dehradun, a hilly town in Northern India. They compared the obtained values with standard values recommended by WHO along with previously recorded values. The comparative analysis of the results made it evident that the overall quality of water has deteriorated rapidly in the last couple of years. The authors made an assessment of the various factors that may have contributed to the decline in water quality and summarized that industrialization, change in life style of local residents and excess use of fertilizers and pesticides are some of the main factors that polluted the water in nearby sources. Such assessments are highly important, since they can serve the purpose of warning the authorities regarding taking necessary steps to regress the rate of water quality deterioration.

The current issue also published some interesting articles that highlighted the indirect effects of environmental pollution. The article by $\mathrm{Hu}$ et al. [5], reported the occurrence of heavy metals in the wheat field soils in Tianjin sewage irrigation region, China. The authors analyzed the samples with the use of ICP-OES and found that they contained Cadmium in the average concentration of $0.46 \mathrm{mg} \cdot \mathrm{kg}^{-1}$ and Zinc in the concentration of $129.08 \mathrm{mg} \cdot \mathrm{kg}^{-1}$. These heavy metals can be absorbed into the plants; these heavy metal intoxicated wheat grains are then sold in local market and consumed by human beings. The authors propose that the heavy metal come from the industrial sewage and gets deposited in the soil. Further analysis of the nearby regions revealed that the total content of the heavy metals are the highest in the "in saline wet fluvo-aquic soil" and "clayification fluvo-aquic soils". The article serves an important purpose of identifying polluted agricultural lands so that they may first be remediated by either phytoremediation or off site treatment before being used for crop cultivation, so that future cases of heavy metal toxicity can be avoided.

The article published by Ubuoh et al. [6], investigated the differences

*Corresponding author: Tarek Heikal, Environmental Toxicology Research Unit, National Research Centre, Cairo, Egypt, Tel: +201002591307; E-mail: tarekhl@yahoo.com

Citation: Heikal T (2017) Journal of Environmental \& Analytical Toxicology, Volume 7; Issue 1. J Environ Anal Toxicol 7: e110. doi: 10.4172/2161-0525.1000e110

Copyright: (C) 2017 Heikal T. This is an open-access article distributed under the terms of the Creative Commons Attribution License, which permits unrestricted use, distribution, and reproduction in any medium, provided the original author and source are credited. 
in the composition of the rain in three nearby regions of an oil producing area in Nigeria. The authors studied the level of corrosion of iron roofing sheet caused after a downpour and found that the mean corrosion rates were the highest in Ibeno marine area, followed by rural Okobo area and the Uyo urban area. The concentration of sulphates, nitrates and chlorides was also the highest in the marine area and was proportional with the gas flare caused by Mobil Oil exploration activities. The results are highly alarming because deterioration of the marine environment due to acid rain can not only damage the water quality of the ocean water but it could also lead to erosion of nearby wetlands and beaches. These effects will impale a long lasting impact on the entire geology and ecology of the region. The study is extremely important and it is recommended that similar studies should also be conducted in other parts of the world, so that the results obtained could help the law makers in identifying the problem and then formulating appropriate remedial policies to limit it.

The Eco toxicological responses elicited in human beings is most of the times the outcome of his own activities. Mankind has learnt to manipulate nature to serve for its own purposes either by cutting hills, drilling holes or re-routing rivers. The article by Davarpanah et al. [7], highlights the environmental implications of one such activity. Drilling with the help of potassium salts is considered highly advantageous, but the toxicological implications of these salts make them less suitable for large scale applications. The authors have conducted a comparative analysis on the efficiency and environmental impact of the usage of formate fluids. The results obtained indicated that using these clean brine fluids for drilling can not only reduce the levels of environmental pollution but it can also reduce the total cost incurred in the entire drilling process. The article can be considered as a standing reference to switch from potassium salt based drilling fluids to formate fluids.

Natural calamities like floods, cyclones and earth quakes have devastating effects on the infrastructure and socio-economic status of the region. The impact of such disasters has a long lasting impact on the society. The article by Bukhari and Rizvi [8], discussed the impact of flash floods that occurred in Pakistan in 2010. The most direct impact was the destruction of 1.93 million acres of standing crops that was coupled with livestock loss; infrastructure damage and loss of personal seed stocks/fertilizers, agriculture machineries and equipments. The total estimated cost of the damage was around Rs. 429 billion. The article appropriately projected the image of a shattered region that is still struggling to return to its formal glory. The most important aspect of the article is that it is an effort by the authors to draw the attention of the scientific community towards the result of improper disaster warning and management strategies.

The information presented in the articles published in the current issue provides a sneak peek into the diversified and critical changes that our environment is going through. Maybe it is time for mankind to step up and start acting more sensibly and save our planet while we still can.

\section{References}

1. Duffus JH (1980) Environmental Toxicology. Edward Arnold (Publishers) Ltd. London, UK.

2. Saad AS, Massoud MA, Amer RA, Ghorab MA (2017) Assessment of the Physico-chemical Characteristics and Water Quality Analysis of Mariout Lake, Southern of Alexandria, Egypt. J Environ Anal Toxicol 7: 421.

3. Manohar S, Mang'oka JM, Ndunda E, Gathuru G (2017) Assessment of Yatta Canal Water Quality for Irrigation, Machakos County, Kenya. J Environ Anal Toxicol 7: 423.

4. Kumar R, Chauhan A, Rawat L (2016) Physico-chemical Analysis of Surface and Ground Water in Selected Sites of Dehradun, Uttarakhand, India. J Environ Anal Toxicol 7: 420 .

5. Hu B, Zhou J, Liu L, Meng W, Wang Z (2017) Assessment of Heavy Metal Pollution and Potential Ecological Risk in Soils of Tianjin Sewage Irrigation Region, North China. J Environ Anal Toxicol 7: 425 .

6. Ubuoh EA, Nwakanma C, Ogbuji S (2017) Atmospheric Corrosion of Corrugated Iron Roofing Sheet in Oil Producing Locations in Southeastern Nigeria. J Environ Anal Toxicol 7: 422

7. Davarpanah A, Zarei M, Razmjoo A (2017) Evaluation of Thermal Stability by Comparison of Potassium Chloride and Potassium/Sodium Formate Fluids. J Environ Anal Toxicol 7: 426

8. Bukhari SIA, Rizvi SH (2017) Impact of 2010 Floods on Pakistan's Agriculture J Environ Anal Toxicol 7: 424 